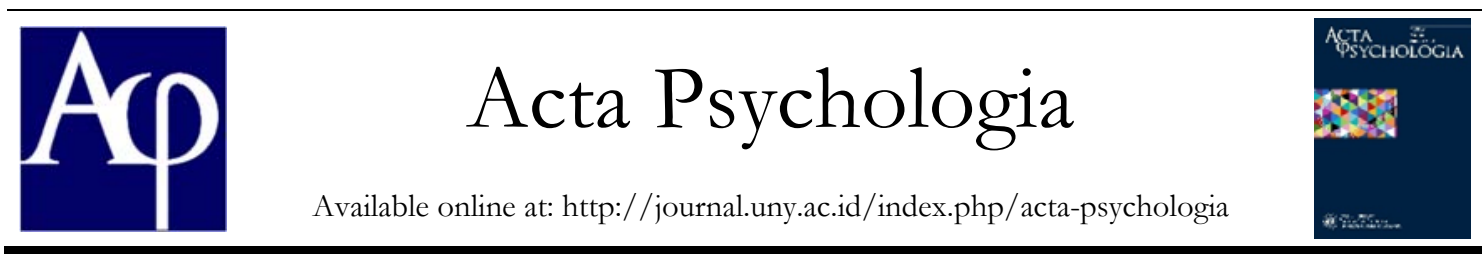

\title{
Hubungan Leader Member Exchange dengan Perilaku Inovatif Kerja: Studi pada Karyawan dengan Pemimpin Perempuan
}

\author{
Widiastuti, Rosita Endang Kusmaryani \\ Jurusan Psikologi, Universitas Negeri Yogyakarta; Jl. Colombo No. 1 Sleman Yogyakarta, 55281 \\ widiastuti0609@gmail.com
}

\begin{abstract}
Abstrak
Tujuan dari penelitian ini adalah untuk mengetahui hubungan antara LMX dengan perilaku inovatif kerja (IWB) pada karyawan dengan pemimpin perempuan. Penelitian ini menggunakan pendekatan kuantitatif dan merupakan penelitian ex-post facto. Subjek yang terlibat adalah karyawan dibawah pemimpin perempuan di Hotel Hyatt Regency Yogyakarta yang berjumlah 58 karyawan. Instrumen penelitian yang digunakan adalah skala leader member exchange dan perilaku inovatif kerja. Hasil seleksi item menunjukkan bahwa angka korelasi item total berkisar antara 0,265-0,841. Hasil uji reliabilitas LMX dimensi afeksi adalah sebesar 0,905, LMX dimensi loyalitas sebesar 0,844, LMX dimensi kontribusi sebesar 0,768, LMX dimensi penghormatan profesional sebesar 0,917, dan perilaku inovatif kerja sebesar 0,937. Berdasarkan hasil analisis product moment, ditemukan bahwa: (1) LMX dimensi afeksi berhubungan dengan IWB, dengan nilai $r=0,361$. (2) LMX dimensi loyalitas berhubungan dengan IWB, dengan nilai $r=0,310$. (3) LMX dimensi kontribusi berhubungan dengan IWB, dengan nilai $r=0,452$. (4) LMX dimensi penghormatan profesional berhubungan dengan IWB, dengan nilai $r=0,505$.
\end{abstract}

Kata Kunci: LMX, perilaku inovatif kerja, pemimpin perempuan

\begin{abstract}
This study investigated the correlation between LMX and innovative work behavior on employees with female leader. This research used quantitative approach and included ex-post facto research. Subjects in this research were employees under the female leaders in the Hyatt Regency Hotel Yogyakarta which amounted 58 employees. Instruments used in this study were leader member exchange scale and innovative work behaviour scale. The result of selection item test showed that the total item correlation values were about $0,265-0,841$. The result for af ection dimension was 0.905 , LMX loyalty dimension was 0.844 , LMX contribution dimension was 0.768 , and LMX dimension of professional respect was 0.917 , meanwhile the IWB scored 0.937 . Based on the product moment analysis, the findings of this study were: (1) LMX af ection dimension is correlated to IWB with $r=0.361$, (2) LMX loyalty dimension is correlated to IWB with $r=0.310$, (3) LMX contribution dimension is correlated to IWB with $r=0.452$, and (4) LMX professional respect dimension is correlated to IWB with $r=0.505$.
\end{abstract}

Keywords: LMX, innovative work behaviour, female leader

\section{Pendahuluan}

Dewasa ini, perkembangan dunia organisasi sangatlah kompleks. Perkembangan dan perubahan yang terjadi dalam sebuah organisasi dapat meliputi berbagai unsur seperti: manusia, tempat kedudukan, tujuan, pekerjaan, struktur, teknologi, dan lingkungan. Masing- masing unsur tersebut tentu saling berhubungan ataupun memengaruhi satu dengan hal lain, serta organisasi atau perusahaan memanfaatkan unsur tersebut sebagai motor penggerak perusahaan. Pada unsur tersebut, terdapat dua hal penting yang menjadi kekuatan dalam organisasi, yakni pimpinan dan karyawannya. Hubungan kedua hal ini tidak dapat dipisahkan satu dengan lainnya, mereka saling melengkapi, serta saling bersinergi. Pimpinan memiliki peranan yang penting dalam memengaruhi 
para karyawannya, begitu pula karyawan berperan dalam stabilitas perusahaan.

Salah satu topik menarik terkait pemimpin ialah pemimpin yang berbasis gender, lebih tepatnya ialah pemimpin perempuan. Kepemimpinan perempuan ini seringkali menjadi polemik dan menyebabkan banyak pro dan kontra pada masyarakat. Terdapat perbedaan persepsi mengenai faktor-faktor pendukung kesuksesan laki-laki dan perempuan. Apabila laki-laki sukses dalam memimpin suatu perusahaan hal itu disebabkan oleh faktor internal dirinya sedangkan apabila perempuan sukses maka disebabkan oleh faktor eksternal misalnya keberuntungan dan situasi lingkungan (Crites, 2015: 3). Menurut Apellbaum, dkk (2014: 43) menyatakan bahwa menurut hasil survei yang telah dilakukan sebanyak 51\% perempuan dari populasi dan $46,5 \%$ tenaga kerja mereka belum mampu menjadi pemimpin atau atasan yang dikarenakan masalah gender. Selain itu Kepemimpinan dibidang bisnis, hanya sekitar dua dari sepuluh wanita yang memiliki posisi sebagai pemimpin $(23,5 \%)$ dibandingkan dengan laki-laki (76, 5\%) (Anonim, 2017).

Berbicara mengenai kepemimpinan, maka tidak telepas dari orang-orang yang bekerja dibawahnya. Hubungan antara pemimpin dan karyawannya inilah yang disebut dengan leader member exchange. Leader member exchange ialah efek perilaku pemimpin yang kepada masing-masing karyawan terhadap motivasi dan hasil tim (Liden dan Maslyn, 1998: 42). LMX ini memiliki empat dimensi yaitu afeksi, loyalitas, kontribusi, dan penghormatan profesional.

Pemimpin harus dapat mengelola sumber daya manusia dengan baik. Artinya, ketika pemimpin memerlakukan karyawan dengan baik maka karyawan juga memiliki kecenderungan akan memberikan kinerja yang maksimal untuk perusahaan salah satunya dengan menunjukan perilaku inovatif kerja, yang akan meningkatkan performa perusahaan. Perilaku inovatif kerja atau Innovative Work Behaviour (IWB) adalah perilaku individu untuk memperkenalkan ide-ide baru yang berguna untuk kemajuan organisasi, yang dapat berupa proses, produk, dan prosedur yang bertujuan untuk mendapatkan keuntungan yang mencakup eksplorasi ide, promosi ide, dan realisasi ide dengan berbagai kebutuhan peran lingkungan organisasi untk mempertahankan hingga mengimplementasikan ide tersebut (de Jong dan den Hartog, 2007: 43-44, 2010: 23-24). Perilaku inovatif kerja ini penting untuk menjaga daya saing organisasi (Hammond, 2011: 4).

Penelitian ini dilaksanakan di Hotel Hyatt Regency Yogyakarta karena perusahaan memiliki salah satu nilai berupa inovasi yang terus dilakukan, serta memiliki salah seorang pemimpin perempuan. Selain itu, Hotel Hyatt memiliki prinsip "We Care to People, so They Can be Their Best" dimana seluruh pekerja yang bekerja di Hyatt memiliki hak yang sama untuk mengembangkan dan memaksimalkan minat dan potensi dalam diri masingmasing karyawan tanpa memandang latar belakang (misalnya agama, gender, jabatan, dan lain sebagainya) yang mereka miliki, sehingga mereka diharapkan memiliki kesejahteraan kerja yang baik ketika bekerja di Hotel Hyatt. Selain itu mereka juga dapat menyampaikan kritik, saran, dan masukan kepada rekan kerja atau pun dengan atasan dengan sangat terbuka. Hubungan atasan dan karyawan pun dinilai baik oleh bagian HRD. Hasil penilaian pihak HRD mengenai hubungan LMX dan inovatif kerja telah baik, namun berbeda dengan beberapa sudut pandang karyawan lain. Beberapa karyawan masih memiliki pandangan yang negatif terhadap pemimpin perempuan. Hal ini menyebabkan sering kali beberapa karyawan sedikit ragu untuk menyampaikan pendapat mereka kepada atasan. Mengenai perilaku inovatif kerja, karyawan sependapat dengan pihak HRD bahwa inovasi yang dilakukan di Hotel 
Hyatt berkembang mengikuti tren yang ada tanpa meninggalkan nilai-nilai lokal, namun untuk inovasi secara individu para karyawan cenderung merasa kurang maksimal.

Berdasarkan uraian di atas, maka permasalahan dan tujuan dari penelitian ini adalah mengetahui hubungan dengan perilaku inovatif kerja di Hotel Hyatt Regency Yogyakarta. Adapun manfaat dari penelitian ini adalah memperkaya kajian konsep LMX dan IWB pada karyawan, baik untuk perusahaan, karyawan, peneliti selanjutnya, maupun para pembaca.

\section{Metode Penelitian}

Penelitian ini merupakan penelitian kuantitatif dan penelitian ex-post facto.

Penelitian ini dilaksanakan di Hotel Hyatt Regency Yogyakarta. Waktu penulisan penelitian mulai dilakukan pada tanggal 27 Agustus 2019, selanjutnya pada tanggal 5 November 2019 hingga 19 November 2019 dilakukan pengambilan data. Penelitian ini selesai ditulis pada tanggal 16 Desember 2019.

Populasi penelitian ini adalah karyawan tetap dibawah pemimpin perempuan di Hotel Hyatt Regency Yogyakarta yang berjumlah 58 karyawan. Subjek penelitian ini melibatkan satu populasi atau seluruh karyawan tetap.

Penelitian ini terdiri dari beberapa tahap. Tahap pertama adalah penyebaran instrumen (skala LMX dan skala IWB) kepada 58 karyawan Hotel Hyatt Regency Yogyakarta. Tahap selanjutnya adalah seleksi item dan reliabilitas. Seleksi item dilakukan dengan menggunakan bantuan program SPSS dan melihat angka korelasi item total. Kriteria pemilihan item berdasarkan korelasi item total biasanya menggunakan batasan $\geq 0,30$. Namun, pada penelitian ini kriteria batasan angka korelasi item total diturunkann menjadi $\geq 0,25$. Hal tersebut sesuai pendapat Azwar (2016: 86) bahwa kriteria batasan angka korelasi item total tersebut dapat diturunkan sedikit batasannya menjadi $\geq 0,25$ apabila jumlah item yang terseleksi masih belum mencukupi (Azwar, 2016: 86).

Data diperoleh langsung dari subjek penelitian. Data tersebut diperoleh melalui 2 instrumen penelitian yang disebar peneliti kepada 58 karyawan Hotel Hyatt Regency Yogyakarta. Adapun instrumen yang digunakan yakni skala LMX dan skala IWB. Skala LMX terdiri atas 35 item, sedangkan skala IWB terdiri atas 24 item. Masing-masing subjek mengisi item-item tersebut (dalam kurun waktu kurang lebih 2 minggu), kemudian skala tersebut dikembalikan ke peneliti.

Teknik analisis data yang digunakan dalam penelitian ini adalah analisis deskriptif dan uji hipotesis. Analisis deskriptif meliputi analisis deskriptif karakteristik subjek dan analisis deskriptif kategori variabel. Uji hipotesis dilakukan dengan melalui analisis product moment.

\section{Hasil Penelitian dan Pembahasan}

Berdasarkan hasil analisis karakteristik subjek, ditemukan data sebagai berikut (dapat dilihat pada Tabel 1 hingga Tabel 4):

Tabel 1. Data Usia

\begin{tabular}{lll}
\hline \multicolumn{1}{c}{ Usia } & Frekuensi & Persentase \\
\hline$<20$ & 6 & $12 \%$ \\
$21-30$ & 25 & $50 \%$ \\
$31-40$ & 9 & $18 \%$ \\
$41-50$ & 10 & $20 \%$ \\
Total & 50 & $100 \%$ \\
\hline
\end{tabular}

Tabel 2. Data Jenis Kelamin

\begin{tabular}{lll}
\hline Jenis Kelamin & Frekuensi & Persentase \\
\hline Laki-laki & 25 & $50 \%$ \\
Perempuan & 25 & $50 \%$ \\
Total & 50 & $100 \%$ \\
\hline
\end{tabular}


Tabel 3. Data Pendidikan Terakhir

\begin{tabular}{lll}
$\begin{array}{c}\text { Pendidikan } \\
\text { Terakhir }\end{array}$ & Frekuensi & Persentase \\
\hline SMK/SMA & 20 & $40 \%$ \\
D1 & 1 & $2 \%$ \\
D2 & 1 & $2 \%$ \\
D3 & 14 & $28 \%$ \\
D4 & 2 & $4 \%$ \\
S1 & 10 & $20 \%$ \\
S2 & 2 & $4 \%$ \\
Total & 50 & $100 \%$ \\
\hline
\end{tabular}

Tabel 4. Data Masa Kerja

\begin{tabular}{lll}
\hline $\begin{array}{c}\text { Lama } \\
\text { Bekerja }\end{array}$ & Frekuensi & Persentase \\
\hline$<1$ & 8 & $16 \%$ \\
$1-5$ tahun & 19 & $38 \%$ \\
$5-10$ tahun & 7 & $14 \%$ \\
$10-15$ tahun & 6 & $12 \%$ \\
$>15$ tahun & 10 & $20 \%$ \\
Total & 50 & $100 \%$ \\
\hline
\end{tabular}

Berdasarkan hasil deskriptif kategori variabel diperoleh data bahwa LMX dimensi afeksi memiliki rerata 36,62 dan standar deviasi yang diperoleh adalah 4,77, sehingga kategorisasi yang dihasilkan adalah sebagai berikut:

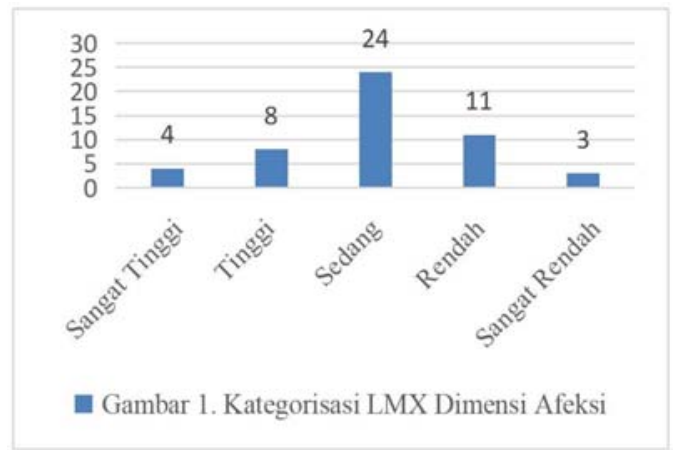

LMX dimensi loyalitas memiliki nilai rerata 38,3 dan standar deviasi yang diperoleh adalah 4,78, sehingga kategorisasi yang dihasilkan adalah sebagai berikut:

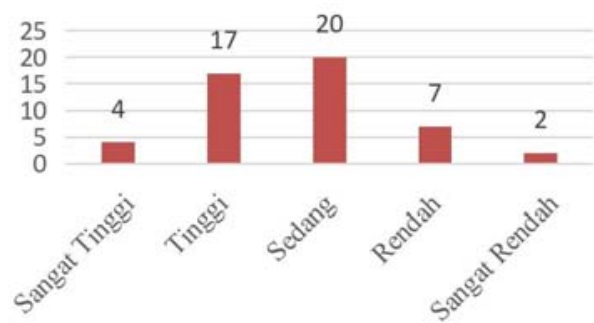

Gambar 2. Kategorisasi LMX Dimensi Loyalitas

LMX dimensi kontribusi memiliki nilai rerata 22,54 dan standar deviasi yang diperoleh adalah 3,34, sehingga kategorisasi yang dihasilkan adalah sebagai berikut:

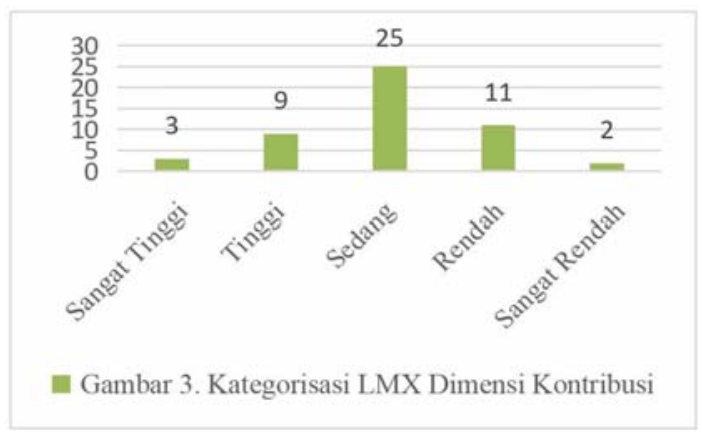

LMX dimensi penghormatan profesional memiliki nilai rerata 36,14 dan standar deviasi yang diperoleh adalah 4,24, sehingga kategorisasi yang dihasilkan adalah sebagai berikut:

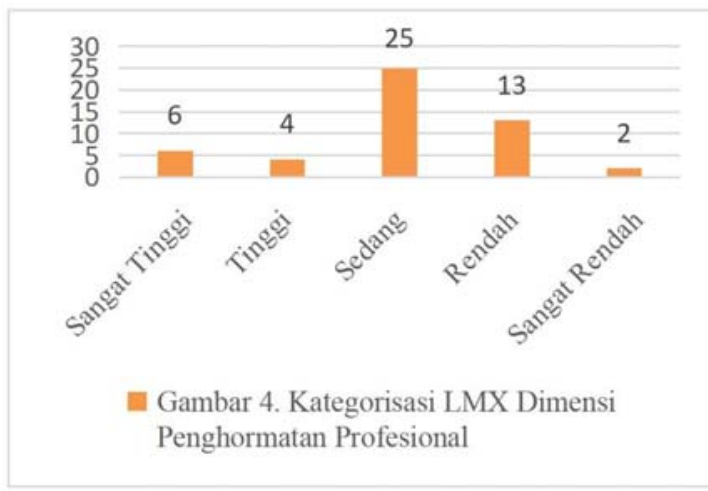

Perilaku inovatif kerja memiliki nilai rerata 87,38 dan standar deviasi yang diperoleh adalah 12,23, sehingga 
kategorisasi yang dihasilkan adalah sebagai berikut:

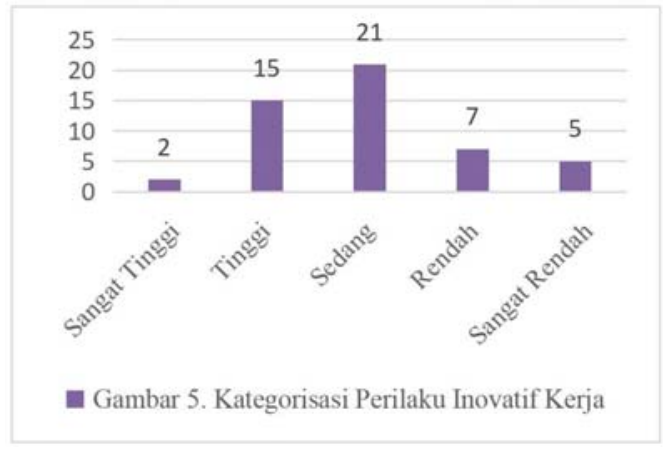

Hasil analisis deskriptif LMX dimensi afeksi menunjukan sebagian besar subjek berada pada kategori sedang yaitu sebanyak 24 orang atau 48\%. Dimensi afeksi merupakan kepedulian atasan dengan bawahan yang dimana mereka memengaruhi satu dengan lainnya dan tidak hanya dari nilai profesional kerja, tetapi dapat berdasarkan pada daya tarik interpersonal (Liden dan Maslyn, 1998: 50). Peran pemimpin perempuan dalam berinteraksi dapat menggambarkan bagaimana dimensi afeksi terhadap para karyawannya ini tercipta. Pemimpin perempuan cenderung memiliki sikap intuitif yang baik, berorientasi pada relasi, memegang nilai-nilai kemanusiaan, peka, dan cenderung kreatif (Sahban, 2017: 70). Karyawan dengan afektif baik cenderung memiliki keinginan untuk menjalin hubungan yang lebih erat dan dekat dengan perusahaan, termasuk dengan sumber daya manusia yang ada di dalamnya.

Hotel Hyatt Regency Yogyakarta memiliki iklim kekeluargaan yang cukup baik (id.indeed.com). Hubungan kerjasama maupun hubungan pribadi antara rekan sesama karyawan maupun antara atasan dengan bawahan terjalin dengan baik. Hal tersebut dibuktikan dengan bentuk perhatian perusahaan yang memberikan fasilitas penunjang bagi tiaptiap departemen, serta pembuatan kebijakan perusahaan yang cenderung tidak menimbulkan kerugian ataupun keresahan pada karyawan. Hal-hal tersebut mampu mempengaruhi rasa kedekatan dan kelekatan emosional karyawan terhadap pemimpin.

Pada penelitian ini juga ditemukan bahwa karyawan dengan lama bekerja ratarata pada rentang 1 sampai 5 tahun. Lama bekerja berhubungan dengan faktor emosional yaitu pembentukan kepercayaan dan hubungan timbal balik. Semakin lama seseorang bekerja dalam suatu organisasi maka akan semakin tercipta pula ikatan emosional yang kuat, pada tahap inilah disebut creation of emotional bond. Pada tahap ini karyawan yang memiliki hubungan baik dengan pemimpin akan masuk dalam in group dan cenderung memiliki komitmen yang tinggi (Spparow dan Liden, dalam Diana, 2018: 32). Selain itu, sebagai bentuk kepedulian atasan dengan bawahan seringkali atasan memberikan penghargaan atau apresiasi atas apa yang dicapai oleh para karyawan. Karyawan di Hotel Hyatt Regency Yogyakarta mengakui bahwa pimpinan tidak segan memberikan pujian ketika mereka berhasil mencapai target kerja.

Hasil analisis deskriptif terkait LMX dimensi loyalitas menunjukan bahwa sebagian besar subjek berada pada kategori sedang cenderung rendah yaitu sebanyak 20 subjek atau 40\%. Dimensi loyalitas merupakan dimensi yang menilai kekonsistenan individu dari satu situasi ke situasi yang lain (Liden dan Maslyn, 1998: 50). Alasan yang memungkinkan hasil LMX dimensi loyalitas dalam kategori sedang cenderung tinggi dapat dilihat pada hasil deskriptif subjek mengenai usia subjek. Mayoritas usia subjek berada pada rentang 21 sampai 30 tahun. Pada usia tersebut termasuk pada generasi milineal. Berdasarkan survey yang dilakukan oleh lembaga survei Doloitte terhadap 10.455 generasi milineal didapatkan bahwa salah satu ciri dari generasi ini adalah tidak loyal terhadap pekerjaannya, mereka cenderung tidak konsisten dalam bekerja hanya 
menjadikan batu loncatan saja (Oscar, 2018).

Namun di sisi lain peran pemimpin perempuan ini penting karena pemimpin perempuan cenderung memiliki kemampuan berkomunikasi yang baik. Kemampuan ini dapat menyebabkan para karyawan tetap menikmati pekerjaan satu dengan pekerjaan lain yang akan menimbulkan kebahagiaan dan akan berdampak pada kenyamanan karyawan sehingga mereka tetap loyal pada pekerjaannya (Proctor, dalam Rosyida, 2017: 15). Hal ini dapat mendukung alasan dari temuan LMX dimensi loyalitas karyawan Hotel Hyatt di bawah pemimpin perempuan sedang cenderung tinggi.

Analisisis deskriptif terkait LMX dimensi kontribusi didapatkan hasil bahwa ratarata berada pada kategori sedang yaitu sejumlah 25 karyawan atau setara dengan $50 \%$ dari total subjek. Kontribusi merupakan seberapa bertanggungjawab karyawan dalam menyelesaikan tugas-tugas yang diberikan melebihi deskripsi pekerjaan (Liden dan Maslyn, 1998: 50). Alasan mengapa dimensi kontribusi ini sedang, hal ini digambarkan oleh lama kerja dan tingkat pendidikan terakhir. Kontribusi juga terikat oleh waktu, semakin lama seseorang bekerja maka semakin banyak pula kecenderungan seseorang berkontribusi pada perusahaan (Liden dan Maslyn, 1998: 52 ). Semakin singkat lama kerja subjek, maka kontribusi yang diberikan pun tidak akan maksimal. Selain itu tingkat pendidikan menurut Green dan koleganya (2006: 47) menyatakan bahwa pendidikan terakhir berhubungan dengan kualitas LMX.

Berdasarkan hasil analisis deskripsi subjek mengenai pendidikan terakhir menunjukan bahwa mayoritas subjek adalah lulusan SMA/SMK sederajat yaitu berjumlah 20 orang atau sekitar 40\%. Kemampuan karyawan dalam memberikan kontribusi yang maksimal juga akan terhambat dikarenakan wawasan dan ilmu pengetahuan yang belum memadai.
Analisis deskriptif mengenai LMX dimensi penghormatan profesional diketahui bahwa 25 orang atau $50 \%$ berada pada kategori sedang. Artinya penghormatan profesional antara karyawan kepada atasan sudah cukup baik. Penghormatan profesional adalah persepsi sejauh mana setiap hubungan timbal balik telah memiliki dan membangun reputasi dalam atau luar organisasi (Liden dan Maslyn, 1998: 50). Penghormatan profesional dapat berupa meminta saran satu dengan yang lain, atau dapat juga mengungkapkan kekaguman atas keterampilan dan integritas orang lain. Alasan mengapa dimensi penghormatan profesional sedang adalah karena berdasarkan hasil angket terbuka, beberapa karyawan (kebanyakan adalah laki-laki) yang menyatakan sedikit canggung untuk memberikan kritik dan saran, karena mereka masih mempresepsikan bahwa pemimpin perempuan lebih sensitif atau "baper". Hal ini sejalan dengan temuan dilapangan terkait jenis kelamin memengaruhi LMX. Staff HRD yang peneliti wawancarai adalah seorang perempuan memiliki perbedaan pendapat dengan karyawan lain yang rata-rata berjenis kelamin laki-laki. Adanya kesamaan demografi yakni jenis kelamin akan jauh mempresepsikan atasan dengan presepsi positif, begitu pula sebaliknya. Hal tersebut menandakan bahwa tingkat penghormatan profesional karyawan pada pemimpin perempuannya cenderung rendah. Namun, di sisi lain penghormatan profesional juga melibatkan tingkat pendidikan, dari hasil temuan dilapangan pendidikan terakhir rata-rata subjek adalah SMA/SMK.

Karyawan dengan pendidikan terakhir setara dengan SMA ini cenderung kagum atas pengetahuan, wawasan, dan keterampilan atasan.

Hal ini dapat menyebabkan tingkat penghormatan profesional cenderung tinggi. Adanya 2 faktor yang berbeda tersebut menyebabkan dimensi 
penghormaatan profesional cenderung sedang.

Analisis deskriptif perilaku inovatif kerja (IWB) didapatkan hasil bahwa sebanyak 21 subjek atau setara dengan $42 \%$ memiliki tingkat IWB yang sedang. Perilaku inovatif kerja sendiri merupakan perilaku individu untuk memperkenalkan ide-ide baru yang berguna untuk kemajuan organisasi, yang dapat berupa proses, produk, atau prosedur yang bertujuan untuk mendapatkan keuntungan yang mencakup eksplorasi ide, promosi ide, realisasi ide dengan berbagai kebutuhan peran lingkungan organisasi untuk mempertahankan hingga mengimplemetasikan ide tersebut (de Jong dan den Hartog, 2007: 43-44, 2010: 23-24).

Alasan yang mendukung mengenai IWB pada subjek di Hotel Hyatt ini sedang karena pertama, berdasarkan hasil analisis deksiptif karakteristik subjek mengenai usia diketahui bahwa mayoritas usia yang bekerja di Hotel Hyatt berada pada rentang 21 sampai 30 tahun yaitu sebanyak 25 orang atau sekitar $50 \%$ dari total subjek. Etikariena (2018: 113-114) menyebutkan bahwa rentang usia 20 tahunan hingga 40 tahunan disebut dengan establishment stage yaitu kelompok usia yang paling memungkinkan menunjukan perilaku inovatif kerja. Pada tahap ini, individu akan mulai menstabilkan posisi kerjanya sehingga memungkinkan untuk mengekspresikan diri. Selain itu, pada tahap ini individu akan menunjukan perilaku yang semakin inovatif, kebiasaan yang positif, dan lebih banyak membangun relasi dengan rekan kerja. Membangun relasi dilakukan untuk persiapan penyerahan pekerjaan pada usia dibawah mereka. Kemudian perbedaan usia juga dapat memengaruhi hubungan kerja tim. Hal ini dikarenakan tim terdiri dari usia yang berbeda akan lebih banyak mengembangkan strategi agresif dan ideide berani tetapi tetap memiliki mekanisme untuk mengevaluasi ide-ide baru (Ostergaard, dkk, 2011: 502).
Selanjutnya berdasarkan jenis kelamin, didapatkan hasil penelitian bahwa distribusi subjek penelitian memiliki besaran yang sama yaitu 25 orang laki-laki dan 25 orang perempuan dengan persentase yang sama yaitu $50 \%$ pada masing-masing jenis kelamin. Isu yang membahas mengenai jenis kelamin memengaruhi performa kerja antara lakilaki dan perempuan terlebih pada perilaku inovatif kerja dinyatakan berpengaruh oleh penelitian dari Ostergaard, Timmerman, dan Kristinson menyatakan bahwa jumlah gender yang cenderung seimbang dalam suatu perusahaan akan membuat sebuah perusahaan lebih banyak berinovasi dibandingkan perusahaan yang memiliki konsentrasi tinggi pada salah satu jenis kelamin (2011: 508). Hal ini berarti baik laki-laki ataupun perempuan memiliki kesempatan yang sama dalam mengembangkan inovasi ditempat kerja.

Disisi lain terdapat temuan yang tidak mendukung dalam hal meningkatkan perilaku inovatif kerja, yaitu lama bekerja dan pendidikan terakhir. Hasil analisis desktriptif subjek berdasarkan pendidikan terakhir yang ditempuh oleh subjek didapatkan kesimpulan bahwa subjek paling banyak adalah lulusan SMA/SMK sederjat yaitu berjumlah 20 orang atau sekitar 40\%. Menurut Janssen (2000: 298), tingkat pendidikan memengaruhi perilaku inovatif kerja. Semakin tinggi tingkat pendidikan seseorang maka semakin tinggi pula perilaku inovatif kerja yang dilakukan.

Pendidikan sangat penting untuk menghasilkan ide, mempromosikan ide, dan merealisasikan ide. Karyawan yang memiliki pendidikan tinggi akan ditempatkan pada pekerjaan yang lebih kompleks dan tidak rutin sehingga memberikan peluang lebih banyak untuk berinovasi. Selain itu, tingkat pendidikan yang tinggi akan lebih banyak seseorang memiliki pengalaman dan pengalaman itulah yang menyebabkan seseorang memiliki banyak wawasan dalam berpikir dan mengembangkan dirinya (Etikariena, 
2018: 114). Hal ini juga diperkuat dengan penelitian yang dilakukan oleh Hammond dan koleganya (Hammond, 2011: 24) yang menyatakan pendidikan berpengaruh pada perilaku inovatif seseorang.

Hal ini dikarenakan ketika seorang individu memiliki pengetahuan dan pengalaman yang lebih banyak mereka akan cenderung merespon suatu masalah dengan lebih terintegrasi yang mencakup ide, fakta, dan kemampuan kognitif lainnya untuk menarik ideide dalam memecahkan suatu permasalahan. Oleh karena itu, pada temuan dilapangan didapatkan hasil yang sebaliknya yaitu pendidikan terakhir mayoritas adalah SMA/SMK sehingga pengetahuan dan wawasannya juga belum memadadai,, sehingga perilaku inovatif kerja para karyawan juga tidak maksimal.

Hasil dari analisis deskriptif selanjutnya yaitu diketahui lama bekerja subjek di Hotel Hyatt Regency Yogyakarta paling banyak menunjukan angka 1 sampai 5 tahun yaitu sebanyak 19 orang atau sekitar 38\% dari total subjek. Hal menarik dari lama bekerja atau masa kerja ialah telah terbukti dapat memengaruhi perilaku inovatif. Semakin lama seseorang bekerja akan semakin matang pula dalam memahami pekerjaannya sehingga akan memungkinkan perilaku inovasi (Etikairena, 2018:115). Selain itu lama bekerja juga memengaruhi komunikasi, semakin lama karyawan bekerja maka semakin baik pula hubungan komunikasi dengan atasan terjalin (Sin dan kolega, 2009: 1053). Berdasarkan hasil temuan dilapangan yang menunjukan waktu lama bekerja yang dinilai masih singkat, maka dapat menyebabkan kontribusi dengan cara memberikan ide-ide juga belum maksimal. Berdasarkan alasan-alasan tersebut, yaitu terdapat hasil analisis deskriptif usia dan jenis kelamin yang mendukung teori-teori yang Pemimpin Perempuan (Widiastuti) memengaruhi perilaku inovatif kerja namun disisi lain didapatkan hasil analisis deskriptif yaitu pendidikan terakhir dan lama bekerja yang berbanding terbalik dengan teori sehingga dimungkinkan menyebabkan perilaku inovatif kerja pada subjek di Hotel Hyatt Regency Yogyakarta ini sedang.

Berdasarkan hasil uji hipotesis melalui analisis product moment, ditemukan fakta bahwa: (1) LMX dimensi afeksi berhubungan lemah dengan IWB, dengan nilai $r=0,361$. (2) LMX dimensi loyalitas berhubungan lemah dengan IWB, dengan nilai $r=0,310$. (3) LMX dimensi kontribusi berhubungan sedang dengan IWB, dengan nilai $r=0,452$. (4) LMX dimensi penghormatan profesional berhubungan sedang dengan IWB, dengan nilai $r=0,505$.

Alasan LMX dimensi afeksi berhubungan lemah dengan perilaku inovatif kerja karena dimensi afeksi yang dimaksud adalah afeksi yang berasal dari pemimpin, bukan dari diri karyawan. Hal tersebut menandakan, afeksi yang dimaksud tersebut berasal dari eksternal bukan internal. Menurut Hammond (2003: 7-10) perilaku inovatif kerja paling kuat dipengaruhi oleh faktor intrinsik. Oleh sebab itu, hubungan LMX dimensi afektif dengan IWB tersebut lemah krena dimensi afektif adalah faktor ekstrinsik.

Alasan yang mendukung LMX dimensi loyalitas berhubungan lemah dengan perilaku inovatif kerja karena dimensi loyalitas sendiri mengacu pada kekonsitenan individu dalam menghadapi situasi satu ke situasi lain, artinya individu cenderung menggunakan cara, metode, teknik yang sama dalam menghadapi masingmasing dalam setiap situasi. Disisi lain, perilaku inovatif kerja membutuhkan dinamika dan caracara berbeda dalam menghadapi setiap masalah. Sehingga alasan tersebut dimungkinkan LMX dimensi loyalitas dan IWB memiliki hubungan yang lemah.

LMX dimensi kontribusi berhubungan sedang dengan IWB karena IWB lebih berhubungan dengan karakteristik pekerjaan bukan karena kontribusi karyawannya. Karyawan yang hanya berkontribusi dengan level pekerjaan 
yang mudah dan cenderung tetap, akan sulit memunculkan perilaku inovatif kerja. Sedangkan karyawan yang berkontribusi pada pekerjaan yang levelnya susah, akan cenderung berusaha mencari ide, menghasilkan ide, dan mengapliksikan ide sehingga akan memengaruhi tingkat IWB. Para pemimpin perempuan cenderung memiliki ambisi dan tekad kuat untuk memberikan yang terbaik untuk organisasinya. Mereka memberikan pengaruh pada karyawan untuk memberikan kinerja yang maksimal pula. Para pemimpin ini akan memberikan contoh sekaligus memberikan tugas. Kedua hal ini mampu mendorong karyawan untuk turut berkontribusi lebih (Fitriani, 2016: 18).Oleh sebab itu, LMX dimensi kontribusi berhubungan sedang dengan perilaku inovatif kerja.

Alasan LMX dimensi penghormatan profesional berhubungan dengan IWB karena salah satu faktor yang memengaruhi IWB adalah kepemimpinan. Penghormatan profesional sendiri yang dimaksud adalah sejauh mana hubungan timbal balik telah dimiliki dan membangun reputasi dalam atau luar organisasi. Perilaku inovatif kerja karyawan tidak hanya bergantung pada kognitif karyawan saja, melainkan dukungan dari pihak eksternal sangat penting salah satunya adalah pemimpin. Kepemimpinan mendorong karyawan untuk melakukan inovasi kerja. Penghormatan profesional dapat dikomunikasikan dengan beberapa cara seperti meminta saran satu sama lain, dapat juga melalui ungkapan kagum. Selain itu kepemimpinan transformasional juga dapat memengaruhi perilaku inovatif kerja.

\section{Gaya} ini memotivasi karyawannya untuk melakukan perubahan kearah yang lebih baik untuk mencapai tujuan bersama-sama (Bass, dalam Krishnan dan Sivinas, 1998: 4-5). Gaya kepemimpinan transformasional dianggap gaya kepemimpinan yang paling banyak diminati oleh karyawan, karena pemimpin dianggap mampu menginspirasi, meningkatkan imajinasi, dan wawasan para karyawannya.

Pemimpin perempuan memiliki karakteristik dimana mereka akan lebih merasa dihormati apabila para karyawannya mau mendengarkan. Pemimpin perempuan merasa bahwa karyawan memiliki respek tinggi terhadap self esteemnya (Allan dan Barbara, dalam Noviani, 2017: 122). Oleh sebab itu pemimpin dianggap penting dalam meningkatkan perilaku inovatif kerja, sehingga LMX dimensi penghormatan profesional berhubungan dengan perilaku inovatif kerja.

\section{Simpulan dan Saran}

Berdasarkan hasil penelitian dan pembahasan, maka diperoleh beberapa kesimpulan. Kesimpulan-kesimpulan tersebut yakni terbukti bahwa ada hubungan antara LMX dimensi afeksi dengan IWB, LMX dimensi loyalitas dengan IWB, LMX dimensi kontribusi dengan IWB, dan LMX dimensi penghormatan profesional dengan IWB

Berdasarkan hasil temuan penelitian ini, didapatkan fakta bahwa LMX berhubungan dengan perilaku inovatif kerja. Oleh karena itu diharapkan perusahaan dapat lebih memperhatikan dan mendukung ide-ide yang dicetuskan karyawan untuk menggunakan kontribusi mereka di tempat kerja untuk melaksanakan perilaku inovatif kerja. Atasan juga sebaiknya memberikan wewenang, tanggung jawab yang lebih besar kepada para karyawan agar dapat memunculkan ide-ide inovatifnya hingga mengimplementasikan ide tersebut.

Berdasarkan hasil penelitian didapatkan bahwa perilaku inovatif kerja karyawan yang menjadi subjek di Hotel Hyatt Regency Yogyakarta memiliki tingkat perilaku inovatif yang sedang. Oleh sebab itu, hendaknya para karyawan dapat meningkatkan kesadaran diri untuk dapat 
berkontribusi dalam meningkatkan IWB memalui menghasilkan ide, mempromosikan ide, dan mengaplikasikan ide.

Saran untuk peneliti selanjutnya adalah diharapkan dapat melakukan penelitian mengenai IWB dengan variabel lain, karena berdasarkan hasil penelitian LMX dengan IWB berhubungan lemah hingga sedang, tidak ada yang tinggi.

\section{Daftar Pustaka}

Apellbaum, S, H., Audet, L., Miller, J, C. (2014) Gender and Leadership? Leadership and Gender?A Journey Through the Landscape of Theories. Leadership and Organization Development Journal, 24(1), 43-51

Azwar, S. (2016). Penyusunan Skala Psikologi. Yogyakarta: Pustaka Pelajar.

Crites, dkk. 2015. Nurturing Gender Stereotypes In The Face Of Experience: A Study Of Leader Gender,Leadership Style, And Satisfaction, Journal of Organizational Culture, Communications and Conflict 19(1)

De Jong, J., den Hartog, D. (2007). How Leaders Influence Employees' Innovative Behaviour, European Journal of Innovation Management, 10(1), 41-64

De Jong, J., Den Hartog, D. (2010). Measuring Innovative Work

Behaviour. Creativity and Innovation Management, 19(1), 23- 36

Diana, Zakirotul. (2018). Hubungan LeaderMember Exchange (LMX) dengan Perilaku Inovatif (Innovatif Behaviour) Pada Karyawan PT. Sentosa Unggul Abadi Surabaya. Skripsi Program Studi Psikologi, Universitas Islam Sunan Ampel Surabaya

Etikariena, A. (2018). Perbedaan Perilaku Kerja Inovatif Berdasarkan
Karakteristik Individu Karyawan. Jurnal Psikologi UNDIP, 17(2), 107118

Green, Connie., Craven, Annete., Scott, J., Gonzalez. (2006). Exploration of The Relationship Between LMX and Demographycs Variabel. Journals of Business and Economics Research, 4(12), 37-50

Gupta, Ashim. 2009. Practical Management Leader Member Exchange.

http://www.practicalmanagement.co $\mathrm{m} /$ LeadershipDevelopment/Leadermember- Exchange.html

Hammond, M, M., Far, J, L., Schwall, A, R., Zhao, X. (2011). Predictors of Individual Level of Innovation in Work: A Meta- Analysis. Psychology of Aesthetics Creativity, and the Arts, 5(1), 90-103

Liden, Robert, C., Maslyn, John, M. 1998. Multidimensionality of Leader Member Exchange: An Empirical Assesment Through Scale Development. Journal of Menegement, 24(1), 43-72

Oscar, Okke. 2018. Survei: Mayoritas Generasi Milenial Tak Loyal dalam Bekerja. Dalam Kumparan.com, dilihat pada 12 Desember 2019

Ostergaard, C., Timmersman, B., Kristinsson, K. (2011). Does a Different View Create Something New? The Effect of Employe Diversity on Innovation. Reseacrh Policy Vol. 40, 500-509

Sahban, Hernita. (2016). Peran Kepemimpinan dalam Pengambilan KeputusanIndonesia. Jurnal Ilmiah Bongaya 